\author{
Инес Црвенковска Ристеска (Северна Македонија) \\ Институт за етнологија и антропологија \\ Природно-математички факултет \\ Универзитет „Св. Кирил и Методиј“ - Скопје \\ е-пошта: ines.crvenkovska@pmf.ukim.mk
}

\title{
ПРЕТСТАВАТА ЗА РОМИТЕ ВО МАКЕДОНСКАТА ЕТНОЛОШКА И АНТРОПОЛОШКА ЛИТЕРАТУРА
}

Апстракт: Релативно е мал бројот етнолошки текстови што се занимаваат со теми поврзани со Ромите на Балканот и во Македонија. Во овој текст, идејата е да се види како се зголемувал интересот за Ромите и како потоа се градела претставата за Ромите во јүгословенската, а од јүгословенската се пренесла сликата во македонската етнолошка и антрополошка литература. За таа цел, во анализата се користени етнографски текстови и зборници посветени на Ромите во периодот на СФР Југославија во 70-тите, 80-тите, 90-тите години, како и текстови за Ромите објавени во Р Македонија од нејзината независност во 1991 г. до денес.

Во дел од овие текстови може да се забележи како етнолозите и антрополозите во своите истражувања ја градат претставата за Ромите во неколку насоки. На самиот почеток во јүгословенската, а потоа со преземање на истиот модел и во македонската етнологија и антропологија се потенцира важноста да се истражува за Ромите како важна југословенска националност, а од друга страна се гради претстава за Ромите и ромската заедница како јүгословенска „другост“ со препорака дека би требало да биде истражувана од етнолози што ќе произлезат од заедницата на Ромите. Како резултат на мотивацијата на југословенско ниво да се ангажираат и Роми етнолози, најголем дел од македонските истражувачи што почнале да се занимаваат со ромската заедница се Роми едуцирани во југословенскиот период.

По распаѓањето на СФР Југославија и концептот за јүгословенската националност составена од братските народи и народности, во рамките на балканските национални програми продолжува да егзистира концептот за ромската „другост“ преку концептот народна традиција кај Ромите. Овој концепт на ромската „другост“ од југословенската етнологија продолжил да се провлекува во текстовите кај Ромите истражувачи во современата македонска етнолошка литература.

Клучни зборови: Роми, етнологија, антропологија, етнолошко-антрополошка литература, балканска „другост“. 


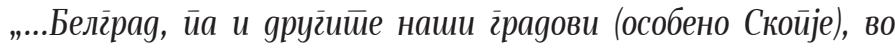

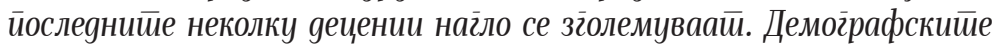

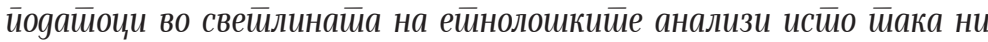

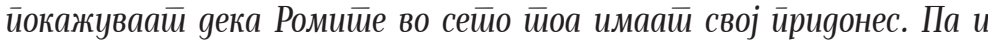

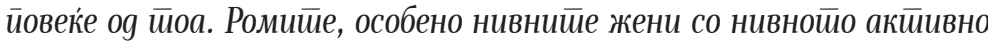

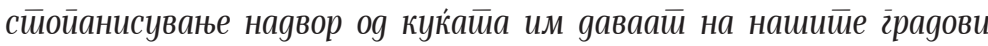

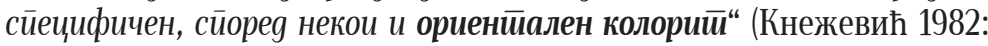
280).

\section{Вовед}

Бројот на етнолошки текстови што се занимаваат со теми поврзани со ромските заедници во СФР Југославија е релативно мал, а уште помалку се текстовите посветени на ромските заедници во Република Македонија по независноста. Во овој текст ќe се обидеме да видиме какви се дискусиите на етнолозите и антрополозите во нивните текстови за Ромите, кои се теориските рамки во кои се градат определени претстави за Ромите во СФР Југославија, коишто, во поголема или помала мерка, се одржале во нивните дела и во периодот по распаѓањето на СФР Југославија, во независна Република Македонија. Како илустрација на овие претстави, во овој текст ќе бидат искористени интерпретации и толкувања од етнографски текстови објавени во зборници посветени на Ромите во периодот на 70-тите, 80-тите, 90тите години на XX век, како и монографски истражувања и текстови обајвени по независноста на Р Македонија до денес. На почетокот во јүгословенската, а потоа со преземање на истиот модел на етнографскиот приод и толкувањата за Ромите и во македонската етнолошка литература се гради ориентализирана претстава за Ромите и за жените Ромки, а истовремено се гради претставата за Ромите како југословенска „другост“. Дискутирајќи за Ромите, авторката С. Кнежевиќ во текст од 1982 година, како во цитатот погоре, за жените Ромки и нивното стопанисување надвор од күќата во југословенските градови, го потенцира нивното присуство во градовите, заклүчувајќи дека тоа им дава на градовите специфичен, ориентален колорит.

Овој текст претставува краток критички осврт кон градењето на ваквиот приод во етнолошките и антрополошките истражувања за Ромите досега. Се разбира, немам намера да биде сфатен како кратка „бајка за моралноста“ (Тодорова 2001: x), ниту пак да биде сфатен како дополнување или исправање на одредени недоследности во истражувањата во периодите претходно. Единствената намера е, со овој текст, да се укаже на потребата од постојано ревидирање на приодите кон социокултурните заедници, вклучително и на ромските, во насока да се зачува релативистичкиот однос во темите за Ромите, третирајќ ги како еднакво сериозни со другите теми во етнологијата и антропологијата.

Градејќи го овој краток критички осврт, ќе се обидеме да се запознаеме со претставите или үште наречените слики во главата (Rot 2000) и нивната употреба во поставувањето одредени „социјални граници“, како што ги нарекува авторката Старк, создадени од етнолозите во текстовите за Ромите, но ќе ги разгледаме 
и причините зошто тие се одржувале во етнографските пишувања до денес. Она што може генерално да се каже е дека основен двигател ваквите ставови да се одржуваат е начинот на кој тие се создадени, врз основа на генерализиции втемелени на редукционизам (Тодорова 2001: 3). Тие истите, во име на „научните факти“, се надополнувани со нови редуцирани генерализации со кои се поддржуваат и одржуваат стереотипите за ромските заедници како „дефиниција за една социокултурна целина“ што постојано се повторува низ литературата.

\section{Југословенската етнологија за Ромите: теориски аспекти во социјалистичкиот период}

Почнувајќи од периодот на 70-тите, потоа во 80-тите и во 90-тите години на дваесеттиот век, јүгословенските етнолози во своите текстови сѐ повеќе се труделе да пишуваат за југословенските Роми или пишувале текстови со кои влијаеле мотивирачки врз етнолошките кругови за да го засилат интересот за истражување на ромските заедници. Нивното влијание било насочено кон нивните колеги, но особено било важно да има ефект меѓу припадниците на ромските заедници. Тоа било така бидејќи работеле согласно со тогашната државна стратегија што се рефлектирала и во високите научни кругови, да се работи во духот на градењето на јүгословенската нација во чии рамки еднакви права и важност имале сите народи и народности во СФРЈ, вклучително и дискусиите за Ромите како засебна народност. Авторите етнолози, пишувајќ за ромските заедници во определен дел на СФРЈ, најчесто ги ставале во корелација со другите ромски заедници низ Југославија, третирајќи ги како една етничка/народносна категорија.

Во оваа смисла, етнолозите активно пишувале во насока на утврдување теориско-методолошка ориентација на јүгословенската етнологија (Бајрактаревић 1982: 155), со цел да се изгради една унитарна јүгословенска етнологија. Оттаму, се предлагало етнолозите да бидат обврзани, во однос на прашањето на методологијата и методот, „да се определат за идеологијата на работничката класа, која е изразена низ марксизмот, за теорија што се темели на дијалектичко-материјалистичка основа“ (Бајрактаревић 1982: 159). На таков начин, работата на етнолозите во социјализмот била ставена наспроти теоријата и методологијата на постарите етнолози одпериодот меѓ двете светски војни, кога „низ антропогеографијата се одржува либералистичкобуржоаската идеологија...“ (Бајрактаревић 1982: 160). Во оваа насока, како особено значајна М. Бајрактаревиќ ја истракнува истражувачката работа и обработката на граѓата за Етнолошкиот атлас на Југославија. Тогаш се развила посебна теорија и методологија на етнологијата на Југославија (Бајрактаревић 1982: 160). Посебен акцент Бајрактаревиќ ставил врз развојот на етнологијата на народите и народностите во Југославија, при што ги предлагал насоките по кои би требало да се движи работата на јүгословенските етнолози, кои „ни слүчајно не може да си дозволат, ни како научни работници, да ги заобиколуваат народностите“ (Бајрактаревић 1982: 156). Така се утврдувале насоките за развиток на југословенската етнологија и во однос на прашањето на Ромите како народност во СФР Југославија. 
Исто така, идејата да се зборува за Ромите, во етнолошката и антрополошката литература, се среќава уште во 80-тите години во текстовите на југословенските и македонските етнолози во СФР Југославија. Во истражувањето за битолските ромски заедници, а во врска со воспоставувањето на терминот Роми (Ром, Ромни), етнологот Константинов напишал дека тоа е термин што битолските Роми го прифаќаат доста бавно во последните години и дека тој термин најчесто е прифаќан од помладите генерации (Константинов 1982: 252) и е сеопфатен за различните заедници што се идентификувани според јазикот и занимањата. Во групата ромски заедници во градот Битола, Константинов ги вбројува заедниците според тоа како се нарекуваат себеси, но за нив дава и одредени дополнителни квалификации што во суштина се замислени традиции за ромските заедници и во суштина се непроверливи и антрополошки нерелевантни: Ѓупци (Еѓупци), Турци Ѓупци, Рисјан Ѓупци-К’пти - за кое Константинов смета дека се губи и се заменува со Македонец, потоа Чергари и Куртофи, при што за првите три групи пишува дека „се сметаат за погорни по потекло од двете последни, што и тие самите се потценуваат, според потсвесно вкоренетите многувековни кастински традиции и сфаќања од Индија“ (Константинов 1982: 252). На тој начин, Константинов, поддржан од другите етнолошки текстови во зборникот од конференцијата од видните југословенски етнолози, предлага да се воспостави истражувачки пристап со кој нема да се двојат Ромите според местото на живеење (град или село). Ваквиот приод за Константинов е „природен“ (Константинов 1982: 247), особено како што тој забележува за случајот со битолските Роми, бидејќи тие претставуваат една единствена етничка заедница, поврзана доста цврсто меѓу себе со разновидните вредности на сопствената духовна и материјална култура. Ваквиот приод во етнолошките истражувања се задржува и деценија подоцна, кај етнолозите што се обидуваат во континуитет да дискутираат за југословенските Роми. Таков приод може да се сретне кај авторката Ѓурѓица Петровиќ во 1992 година, која е задоволна од 508-те и повеќе библиографски единици посветени на Ромите дотогаш, па зборува за бројно импозантни трудови во кои се опишани југословенските Роми во кои „во најголем дел е опфатена етнолошката заинтересираност за оваа самосвесна и автентична етничка заедница“ (Петровић 1992: 61). Со ваквиот етнолошки став на југословенските истражувачи, на Ромите се гледа како на една монолитна заедница, врз чија „природна“ поврзаност во единствена етничка заедница може да се гради концептот за ромската народност во рамките на југословенската нација-држава.

Ова укажува на фактот дека во етнолошката и антрополошката литература за Роми многу појасно се зборува во 90-тите години, на конференција за Ромите. Тогаш Саит Балиќ, претседателот на Меѓународната организација на Ромите, ја истакнал карактеристиката на Ромите според која тие се оние што „ги поминале сите Сцили и Харибди, кои ги истрпиле сите неправди и понижувања, кои, на својот долг пат од Индија до сите останати подрачја на светот, поминале не нанесувајќи на никого неправда и зло, (и) знаат да го ценат секој човечки гест и чин што е испреплетен со идејата за човечност“ (Балић 1992: 3).

Во смисла на тоа од кога точно може да се зборува за пофокусирано следење на ромската култура во Југославија зборува академикот Милош Мацура во воведниот текст на научниот собир посветен на „Развитокот на Ромите во Југославија - проблеми и тенденции“ во 1992 година, кога ја нагласува важноста на организираниот научен 
собир во 1976 година од страна на САНУ со наслов „Животот и обичаите на Ромите во нашата земја“, кога било предложено Академијата во иднина да посветува поголемо внимание на ромските студии и за таа прилика да основа одговорно тело. Така, Претседателството на САНУ се сложило во 1977 година, во рамките на Етнографскиот одбор, да биде основана посебна Работна група за проучување на Ромите. Поради недостиг на кадри и средства за научноистражувачка работа, групата била расформирана во 1978 година. Но, идејата за проучување на животот и обичаите на Ромите не била напуштена. Напротив, се сметало дека во Сараево и Скопје, каде што, според мислењето на специјалистите, била унапредена работата на проучувањето на ромскиот јазик и другите манифестации на духовниот живот на Ромите, „ќе биде иницирано основање на меѓуакадемиски одбор, со што и потребите на САНУ за работа на оваа важна материја би биле решени“ (Мацура 1992: 1).

Во 90-тите години ситуацијата во односот на етнолозите кон истражувачките теми за Ромитевидно се менува; имено, станува модерно да сепишува за Ромите, но ида се пишуваат мотивирачки текстови во кои се потенцира значењето да се истражуваат теми поврзани со Ромите, во кои особено се поттикнуваат Роми да се занимаваат со етнолошки теми. На тој начин се поттикнуваат истражувања „одвнатре“, што е случај со сите заедници во СФР Југославија во тој период. Во слүчајот со Ромите, во истражувања во овој период може да се види истражувачки дискурс кон Ромите како кон маргинализирана група, да се следи социјалната политика на државата кон нив и веќе да се прават истражувања во врска со предрасудите и стереотипите поврзани со ромското население. Во оваа смисла, во една прилика, авторката Петровиќ ќе напише дека „сите наменски трудови за Ромите во Југославија... претставуваат солидна основа за дополнување и продолжување на започнатите дела на досегашните истражувачи на Ромите. Од 70-тите години на нашиот век (XX век, заб. И. Ц. Р.) оживеа интересот на научниците... за оваа етничка заедница што сѐ үште се наоѓa на општествените маргини“ (Петровић 1992: 62). Притоа, оваа појава ја става во контекст на важноста од раздвижување меѓу Ромите за промена на нивниот статус и положба во општеството воопшто, „....како и вклучување поголем број истражувачи од повеќе научни дисциплини во проучување на минатото и сегашноста на југословенските Роми“ (Петровић 1992: 62). Како резултат на ваквата мотивирачка енергија во овој период, ќе се зголеми бројот на етнолози Роми во јүгословенската етнологија што ги истражуваат ромските заедници од 70-тите години наваму, со што се засилува инсајдерскиот пристап во истражувањата на ромската култура што се сметал за најверодостоен. Секако, тоа придонело за продлабочени и поиздржани квалитативни истражувања, а се засилувала и позицијата на припадниците на ромската народност во истражувачките институции и кругови. Во оваа смисла, од Ромите истражувачи, тие што имале можност да бидат во високите научноистражувачки институции на СФР Југославија, како што е Претседателството на Српската академија на науките и уметностите, до 90-тите години успеале да организираат три научни собири посветени на Ромите во Југославија. На овие настани тие со голема благодарност се обраќаат на „пријателите на ромскиот народ, со векови напатен и намачен и во современата цивилизација, во чија судбина се впишани и искажани сите неправди и сите зла на современиот свет“ (Каназир 1993: 3). 


\section{Воспоставување на ромската „другост“ во југословенската етнологија}

Сребрица Кнежевиќ во текстот на посветен на „Жените на Ромите и нивната смисла за адаптација во склад со економските промени“ од 1982 година, објаснувајќи ги теориските претпоставки во нејзината анализа што се темели на опфатен период од 50 години, ја насочува главната цел кон расветлувањето на низата заемно зависни прашања почнувајќи од интензитетот на инфилтрација на вечните номади во градскиот амбиент, преку нивното врзување за постојана територија и преку стекнување навики на седентарен живот низ еден вид адаптација на економско поле (Кнежевић 1982: 280). Ваквата квалификација и третман на Ромите како „вечни номади“ може да се забележи и кај други автори етнолози во овој период, но и кај македонските автори во периодот на 90-тите години, со што продолжува да се гради претставата за Ромите во Битола како необично подвижни зашто и вечното движење е одлика на нивната немирна скитачка крв (Константинов 1982: 267).

Авторката Кнежевиќ, со оглед на граѓата со која располагала во гореспомнатото истражување, работната хипотеза ја насочува кон тежнеење да се набљудува влијанието на градската средина врз Ромите (кога Ромите прифаќаат и се приспособуваат на градската средина) повеќе отколку кај другите етнички заедници, и многу повеќе изменувањето и адаптацијата на навиките и обичаите на градската средина кон традицискиот ромски стил на живеење. Ова може да се согледа, според авторката Кнежевиќ, ако се следи улогата на жените на Ромите, односно циг̆анскийе жени, за кои смета дека дале голем придонес во воспоставувањето на економската меѓузависност на ромските жени со градската средина, како бајачки, исцелителки, претскажувачки на судбината, растурачки на црна магија, препродавачки на текстил и куќни помошнички по Втората светска војна. Вториот важен аспект во приспособувањето го гледа во тоа што „не мал број убави и млади го продолжуваат традиционалното занимање на Циганките - пејачки по многуте кафеани во внатрешноста (на државата, заб. И. Ц. Р.)“ (Кнежевић 1982: 288). За истото пишува и авторот Константинов, кој за битолските Ромки генерализира дека „се интелигентни жени кои вражаат и гатаат“ (Константинов 1982: 268).

\section{Природна поврзаност на Ромите}

Конкретно, авторот Константинов по потекло од тогашна Социјалистичка Република Македонија, уште во текстот од 1982 година, „природната“ поврзаност на Ромите ја утврдува врз основа на определени антрополошки особини, на колективната здравствена состојба, духовните одлики што го чинеле ромскиот 
менталитет и низа други карактеристики поради кои, според него, би требало да бидат ставени во една категорија „народност“. Обидувајќи се да зборува за ромските антрополошки особини, авторот Константинов најпрво зборува за потребата од систематски и комплетни антрополошки мерења, кои дотогаш не се вршени врз оваа заедница, поради што антрополошките особини ги утврдува „врз основа на подолги визуелни набљудувања“ (Константинов 1982: 255-256). Така, тој забележува дека антрополошките особини може да се утврдат според обликот на главата, па генерализира дека се среќава доликокефален, брахокефален и мезокефален облик на главата, и дека најчесто Ромите се со доликокефален облик на главата. Оваа произволна карактеристика за Ромите ја дополнува со најзастапените „расни“ одлики на Ромите според кои косата им е црна, очите исто така; веѓите им се густи, цртите на лицето главно правилни. Според него, и мажите и жените се одликуваат во мнозинство со убави лица, со тен што варира од не многу затворен до поотворен, посветол, па дури и на нијанса на бело; дека меѓу мажите има мошне добро и атлетски градени луѓе. Континуитетот на ромската заедница авторот Константинов го гледа во континуитетот на убавината на ромските жени и девојки, кои ги вбројува, а според него се такви и во периодот за кој тој зборува, во поголемите балкански убавици. Меѓу важните карактеристики ги истакнува телесните одлики на Ромките, кои „се поразвиени во горниот дел од телото, па често имаат необично бујни гради“. Малите деца се симпатични и убави, еднакво од двата пола. Во однос на нивните духовни одлики, Константинов се обидува да ги извлече нивните најголеми вредности, па зборува за тоа дека битолските Роми се весели и разиграни луѓе, без оглед на тоа дали се наоѓаат во добра или во некоја непријатна и лоша положба; дека се мошне духовити и често се смеат искрено и весело; дека за нив пеењето, играњето и свирењето се најголеми вредности во секојдневниот живот, па, штом не се на работното место каде што не може да постапуваат слободно, денот го почнуваат со песни и свирки; вечерта ја пречекуваат на ист начин, а некогаш таа продолжува и длабоко низ ноќта, додека се преуморат и капнат за спиење. Извлекува одредени карактеристики поврзани со идејата за нивниот темперамент како немирни, живи, лесно избувливи, но во основа мирољубиви, кои ретко се степуваат со странци, а почесто меѓусебно. За да го потврди тоа, Константинов оваа одлика ја илустрира со замислена случка на караница поради употребен навредлив збор, а оттаму и тепачка. Така, во обидите да ја илустрира нивната склоност кон тепачки, истовремено зборува за тоа дека во последните неколку години избувнале само две-три општи тепачки. Илустрацијата на ситуацијата со тепачката Константинов ја надополнува со сликата кога „сите возрасни жители излегуваат со отпорано подготвени специјални стапови. Штом ќе се судрат мажите, удирајќи секој по секого и по виновни и по прави, се замешуваат и жените и децата, во својство на смирувачи. Тие навлегуваат меѓу судрените и ги влечат кон дома. Целата опасна врева стивнува штом ќе се појават униформираните заштитници на редот и мирот“" (Константинов 1982: 268). Оваа претстава на емоционална неурамнотеженост, Константинов ја надополнува со тоа дека Ромите често стануваат меланхолични, па „во таквите мигови на општа меланхолија се разнежуваат како галени мали деца...”. 


\section{Ромската „другост“ и во македонската етнологија}

По независноста на Република Македонија од СФР Југославија во 1991 година, на почетокот побавно, а подоцна позабрзано настапил период на национализација на општествените и хуманистичките дисциплини и институции, па станало многу важно тежиштето во истражувањата да се насочи кон македонската национална култура. Така започнал да се намалува бројот на истражувачи што се занимаваат со теми поврзани со ромските и другите етнички заедници, па бројот на истражувачи на ромските заедници се свел на истражувачите Роми, кои во Македонија денес се во помал број. Во оваа смисла, и во истражувачките институции продолжила поддршката на идејата од јүгословенскиот период, културата на помалите заедници да ја истражуваат истражувачи инсајдери, истражувачи од заедниците, како најкомпетентни да истражуваат и пишуваат за теми поврзани со контекстот од кој доаѓаат. Исто така, нема промени во теориско-методолошкиот пристап во истражувачката работа и трендовите во изборот на истражувачки теми на ромските истражувачи, па во најголем дел не отстапуваат од дотогашниот приод, да се следи „традиционалната култура на Ромите во Македонија, проследена преку разните етнолошки појави, систематизирани во трите нејзини сегменти - материјалната, социјалната и духовната култура“(Петровски 20136:6). Според пишувањата на авторот Петровски, културата на Ромите би требало да се следи преку овие три најважни сегменти со кои е опфатен начинот на живот во ромската заедница во РМ. Но, со текот на времето се покажало дека ваквата традиционалистичка категоризација во истражувачкиот пристап за ромската култура наследена од етнолошката наука од почетокот на дваесеттиот век не може да одговори на истражувачките потреби подоцна, кога се наметнало прашањето како да се истражуваат современите социокултурни контексти во ромските заедници.

Тоа покажува дека, иако во периодот на 70-тите и 80-тите години во југословенската етнологија големо внимание се посветува на културите на националностите и истражувачите од националностите, по независноста на балканските републики, меѓу кои и Р Македонија, оваа стратегија за засилена едукацијанамладиетнолози Роми сеизоставакаконеважна.Македонскатаетнологија, немајќи идеја каков третман да ѝ даде, ја става во позиција на маргинализирана култура, а истражувачите Роми, едуцирани за време на СФР Југославија, што се сега веќе во изминати години, продолжуваат да пишуваат за ромските заедници на истиот начин, односно квалитетот на истражувањата үште и ослабува поради тоа што веќе во периодот по 2010 година започнуваат текстовите да ги реплицираат без контекстуализација на темата во современ социокултурен контекст. 


\section{Претставата за „другоста“ на Ромите во македонската етнологија и антропологија}

Во периодот по независноста на Р Македонија од СФР Југославија во 1991 година, мал е бројот Роми етнолози, и тие најчесто пишуваат текстови без никакви обиди да излезат од зоната на традицискиот комфор каде што концептот народна традиција е фокусот на истражүвањата. Оттука, истражүвањата поврзани со современите ромски контексти во овој период се во мал број или скоро ги нема. Тие стануваат интересни во периодот по 2010 година за истражувачи што не се Роми и за истражувачи што не се од Република Македонија.

Во раниот период по 2010 година, приодот на Ромите етнолози во истражувањето на ромската култура го држи истиот правец, па во поголемиот број текстови преовладува концептот во кој ромската традиција е видена преку примерот на календарските обичаи. За разлика од нив, други истражувачи што не се Роми и се интересираат за народната традиција, во концептот народна традиција вклучуваат и процеси на нејзина трансформација во современата култура, повторно видена преку трансформацијата на обичаите за празниците Василица и Гурѓовден.

Во текстовите на ромските истражувачи, пак, едуцирани во периодот на СФР Југославија, може да се забележи постапка на репликација на текстовите за ромската традиција од 80-тите години во етнолошките изданија по 2010 година. Таа репликација на текстовите оди дотаму што во македонската етнолошка литература може да се сретне пример каде што еден текст публикуван во едно стручно списание во 80-тите или 90-тите години, со незначителни приспособувања и без дополнување со етнографски податоци или етнолошка анализа на етнографски материјал што би кореспондирала со современиот контекст, се реиздава во 2013 година, во друго стручно списание, под нов наслов. Па така, и во овој текст како и во тие во 80-тите години, за Ромите и понатаму продолжува да биде важен обликот на главата воочен со подолготрајни набљудувања како важен научен доказ дека Ромите се физиолошки блиски со претставници на некои народи во Северна Индија.

Ваквиот научен и истражувачки пристап во македонската етнологија и антропологија, независно дали е од Роми истражувачи или не, придонесува за понатамошно поддржување на стереотипите создадени за јүгословенските Роми од 70-тите и 80-тите години во југословенската етнологија во кои концептот народна традиција на Ромите е претставен како нединамичка и тешко менлива категорија, што оди во прилог на идеите и претставите за Ромите од 70-тите и 80-тите години, под изговор дека се научно оправдани без да бидат консултурани податоци од современиот ромски социокултурен контекст. 


\section{ЗАКЛУЧОК}

Во овој текст се искористени интерпретации и толкувања од етнографски текстови објавени во зборници посветени на Ромите во периодот на 70-тите, 80-тите, 90-тите години на XX век, како и монографски истражувања и текстови објавени по независноста на Р Македонија до денес, со цел да се види каква претстава се гради за Ромите во југословенската, а потоа со преземање на истиот модел и во македонската етнолошка литература. Од една страна се гради ориентализирана претстава за Ромите и Ромките како југословенска „другост“, а од друга страна се гради концепција во која ромската заедница се набљудува преку тешко менливата категорија - ромска традиција.

Ваквиот научен и истражувачки пристап во македонската етнологија и антропологија, независно дали е од Роми истражувачи или не, придонесува за понатамошно поддржување на стереотипите создадени за јүгословенските Роми од 70-тите и 80-тите години во југословенската етнологија во кои концептот народна традиција на Ромите е претставен како единствена област на интерес што може да покаже дека оваа заедница е нединамичка и тешко менлива категорија. Тоа оди во прилог на идеите и претставите за Ромите од 70-тите и 80-тите години, кои истражувачите продолжуваат да ги поддржуваат под изговор дека се научно оправдани без да бидат консултурани податоци од современиот ромски социокултурен контекст. 


\section{ЕтноАнтропоЗум}

\section{Литература}

Бајрактаревић, Милун. 1982. „Теоријско-методолошка оријентација југословенске етнологије“. Ейнолошки ӣрег̈леg 17, 155-162.

Балић, Саит. 1992. „Поздравна реч Саита Балића, претседника Међународне

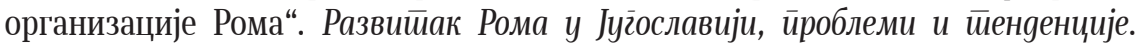
Научни скупови LXVIII (1). Београд: САНУ, Одељење друштвених наука, Комисија за проучавање живота и обичаја Рома, 3-4.

Каназир, Душан. 1993. „Поздравна реч академика Душана Каназира, претседника САНУ“. Друшишвене йромене и йоложај Рома. Научни скупови LXX (2). Београд: САНУ, Одељење друштвених наука, Комисија за проучавање живота и обичаја Рома, 3-4.

Кнежевић, Сребрица. 1982. „Жене Рома и њихов смисао за адаптацију у складу са

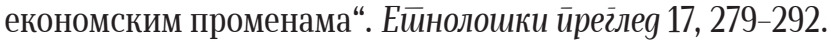

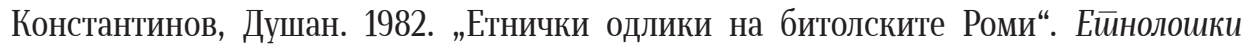
йрег̈леg 17, 247-278.

Мацура, Милош. 1992. „Уводна реч академика Милоша Мацуре“. Развийак Рома у Југіославији, йроблеми и йенgенције. Научни скупови LXVIII (1). Београд: САНУ, Одељење друштвених наука, Комисија за проучавање живота и обичаја Рома, $1-2$.

Петровић, Ђурђица. 1992. „Научна истраживања Рома у Југославији“, Развийак Рома y Југіославији, ирроблеми и йенgениије. Научни скупови LXVIII (1). Београд: САНУ, Одељење друштвених наука, Комисија за проучавање живота и обичаја Рома, 61-83.

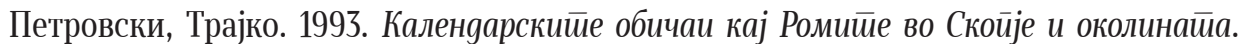
Скопје: Феникс.

Петровски, Трајко. 2013а. „Етнокултурните карактеристики на Ромите во Крива Паланка“. Славишки зборник 2. Крива Паланка: Градски музеј, 239-251. 


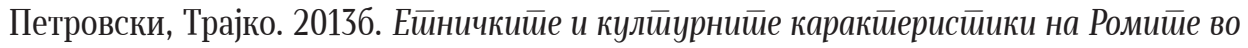
Макеgонија. Посебни изданија, книга 82. Скопје: Институт за фолклор „Марко Цепенков“.

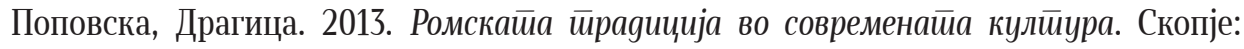
ИНИ.

Старк, Еја. 2016. „Политиката на фолклорот, начинот на неговото собирање: фолклорот поврзан со ромското население во Финска во раниот 20 век“.

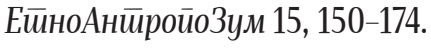

Тодорова, Марија. 2001. Замислувајќи г̇о Балканой. Скопје: Магор.

Rot, Klaus. 2000. Slike u glavama. Ogledi o narodnoj kulturi u jugoistočnoj Evropi, 113. Ivan Čolović (ur.). Beograd: Biblioteka XX vek. 